\title{
The Harvard Semitic Museum Palmyrene Collection
}

\author{
Eleonora Cussini, Maura K. Heyn, Jeremy M. Hutton, \\ Nathaniel E. Greene, and Catherine E. Bonesho
}

\begin{abstract}
Three Palmyrene funerary busts are part of the collections of the Harvard Semitic Museum. This article discusses the epitaphs, the portraits, and their stylistic features, summarizes the funerary busts' documented history of possession, and offers a palaeographic analysis of the inscriptions.
\end{abstract}

Keywords: Palmyra; funerary portraiture; Palmyrene Aramaic; Palmyrene epigraphy; Palmyrene palaeography

$\mathrm{T}$ hree Palmyrene funerary busts are part of the collections of the Harvard Semitic Museum. These previously unpublished inscribed limestone portraits depict two men (HSM 1894.3.1; HSM 1894.3.2) and one woman (HSM 1902.45.29). Several thousand portraits, created in the first three centuries C.E., have come from Palmyrene tombs, where they served to seal burial niches and commemorate the dead. These portraits were traded actively on the antiquities market in the 19th and early 20th centuries and are found today in museums and private collections in Syria, Turkey, across Europe, and in the United States. Funerary reliefs of this type continue to emerge in the collections of Western

Eleonora Cussini: Department of Asian and North African Studies (DSAAM), San Polo 2035, Università Ca’ Foscari Venezia, 30125 Venice, Italy; cussini@unive.it

Maura K. Heyn: Department of Classical Studies, University of North Carolina, Greensboro, Greensboro, NC 27402; mkheyn@uncg.edu

Jeremy M. Hutton: Department of Classical and Ancient Near Eastern Studies, 960 Van Hise Hall, 1220 Linden Drive, University of Wisconsin-Madison, Madison, WI 53706;

jmhutton@wisc.edu museums, some having entered those collections over a century ago (see, e.g., Albertson 2012; Hutton et al. forthcoming; and Hutton and Klein 2018). ${ }^{1}$ Due to the manner in which they were traded, the Harvard Semitic Museum portraits, like numerous other examples, lack specific provenance records, and we cannot identify the tombs from which they originated. The Harvard Semitic Museum inscriptions are not dated, and as such we rely

\footnotetext{
1 The Palmyrene statuary and inscriptions published here are documented to have been in the collection of Harvard University's Semitic Museum long prior to April 24, 1972, the date of entry into force of the 1970 UNESCO Convention on the Means of Prohibiting and Preventing the Illicit Import, Export, and Transfer of Ownership of Cultural Property.
}

Nathaniel E. Greene: Department of Classical and Ancient Near Eastern Studies, 910 Van Hise Hall, 1220 Linden Drive, University of Wisconsin-Madison, Madison, WI 53706; ngreene@wisc.edu

Catherine E. Bonesho: Department of Near Eastern Languages and Cultures, 376C Humanities Building, University of California, Los Angeles, Los Angeles, CA 90095-1511; bonesho@ucla.edu 
upon stylistic characteristics to place them into chronological groups (see below).

The purpose of this study is to make these inscribed reliefs available for further discussion and study. This is particularly important after the recent dramatic events that led to the destruction of hundreds of Palmyrene artifacts still in situ or housed in the former Museum of Palmyra.

\section{The Inscriptions}

\section{HSM 1894.3.1: Relief-Bust of a Youth before a Dorsalium (Museum Registration No. 1272) (Fig. 1)}

1. $m l^{\prime}$ Malē,

2. $b r \quad$ son of

3. mqy Maqqay.

4. hbl Alas!

The first rectangular limestone relief $(58 \times 41 \mathrm{~cm})$ depicts a youth with two book rolls in his left hand, before a curtain or dorsalium held by round pins and palm fronds. The four-line epitaph is carved to the right of his head in horizontal lines (Figs. 2, 3, detail of inscription). The monumental-style letters are neatly carved and are framed by the palm frond (see below). It is a typical epitaph, which records the name and patronym of the deceased and is followed by the usual exclamation of grief, $h b l$, "Alas!" The presence of the curtain hints at the possibility that this might originally have been a double portrait, depicting the deceased, Malē, and a sibling or another relative to his left (cf., e.g., the double bust in Ploug 1995: 208-10 no. 85, in which only one of the figures is backed by a curtain). The possible missing part of the original relief is now lost. However, in the surviving background portion beyond the palm frond, there are remnants of the ending of two or three lines: perhaps a resh, roughly corresponding to the third line of Malès epitaph, and a lamed, corresponding to the fourth (see Figs. 2, 3, to the right of the palm frond [marked in gray in Fig. 3]). This other epitaph identified a relative who had died after Malē, as the presence of the curtain could indicate (see below). Whether the layout of this epitaph corresponded to that of Male or consisted of two or three lines only, it is impossible to say on the basis of the surviving evidence. As other examples indicate, portraits were sometimes reduced to ease transportation and sale once they had been removed from their setting prior to modern scientific excavation of the tombs.

Both the name and patronym are widely attested: Malē, $m l$ ', a hypocoristicon of Maliku, mlkw, and phonologically identical to $m l y$, frequently occurs in Palmyrene onomastics (Stark 1971: 95). Malēs patronym, Maqqay, a hypocoristicon of Mokimu, mqymw, is similarly widespread (Stark 1971: 96). The epitaph does not make reference to his profession. However, the presence of book rolls in his hand could be a visual reference to an occupation involving writing or, in general, to Malès literacy. In light of his apparently young age, this could hint at the fact that he was still a pupil. ${ }^{2}$ Given the lack of additional information, it is difficult to connect this Male and Maqqay to other Palmyrene inscriptions. A reversed sequence of a father Malē and his son Maqqay in PAT 2828, the epitaph of Ummabi, daughter of Maqqay, (son of) Malē, (son of) Lu'ash, could refer to the same family.

\section{HSM 1894.3.2: Relief-Bust of a Bearded Man (Museum Registration No. 1273) (Fig. 4)}

\section{1. slm hyrn br The statue of Hayran, son of \\ 2. $b s^{\prime} / n s^{\prime}$ hbl Bassa' (or Nesa'). Alas!}

The second relief depicts a bearded man $(49 \times 43 \mathrm{~cm})$. A two-line, cursive-style inscription is carved vertically to his right (Figs. 5, 6, detail of inscription). The cursive style and the vertical orientation of the epigraph set this epitaph apart from the other two inscriptions (see below). Another difference concerns its formulation: The epitaph opens with the noun șlm, "statue, image," in construct with the man's name, Hayran, hyrn. This element, and its feminine counterpart șlmt, used in women's epitaphs, occurs repeatedly throughout the corpus, in combination with the personal name of the deceased (PAT 1996: 402-3; Cussini in Meischner and Cussini 2004: 102-3). ${ }^{3}$ This combination may also occur in epitaphs ending with the exclamation of grief $h b l$, and in other instances, the interjection $h b l$ is not recorded. ${ }^{4}$

The name Hayran is widely attested in the corpus (Stark 1971: 21-22). It is a one-word name meaning "good, excellent," cognate with Arabic hayr, with the same meaning, and the addition of the adjectival suffix -ān (Stark 1971: 88). The patronym is Bassa', $\left(b s^{\prime}\right)$, or, according to the different interpretation of the first letter as nun, Nesa', (ns') (as suggested by Hutton, Greene, and Bonesho). Both Bassa' and Nesa' are well-known Palmyrene names. Bassa' may be analyzed as deriving from Arabic bass, "cat" (Stark 1971: 77). An interpretation in

\footnotetext{
${ }^{2}$ For other suggestions, see below.

${ }^{3}$ The same formulation of șlmt + PN referring to images of women is found in Old Syriac and Hatran inscriptions (Drijvers and Healey 1999: nos. As6, As13; Aggoula 1991: nos. 5, 30, 34, 37).

${ }^{4}$ The formulation șlm without $h b l$ may occur on the same types of artifact, i.e., busts, or on sarcophagi and group reliefs, and in dipinti on tomb walls. Note on the same relief with multiple epitaphs, șlm and șlmt $\mathrm{PN}+h b l$ s slm PN, and PN only (PAT 1893); or șlm and șlmt PN, and PN $h b l$ (PAT 1894) (see also PN + ḥbl, and șlm PN + ḩbl [PAT 1892]). It is generally assumed that when the group relief was commissioned, dead family members were indicated by $h b l$ or by a curtain pinned behind their portrait (Colledge 1976: 78).
} 


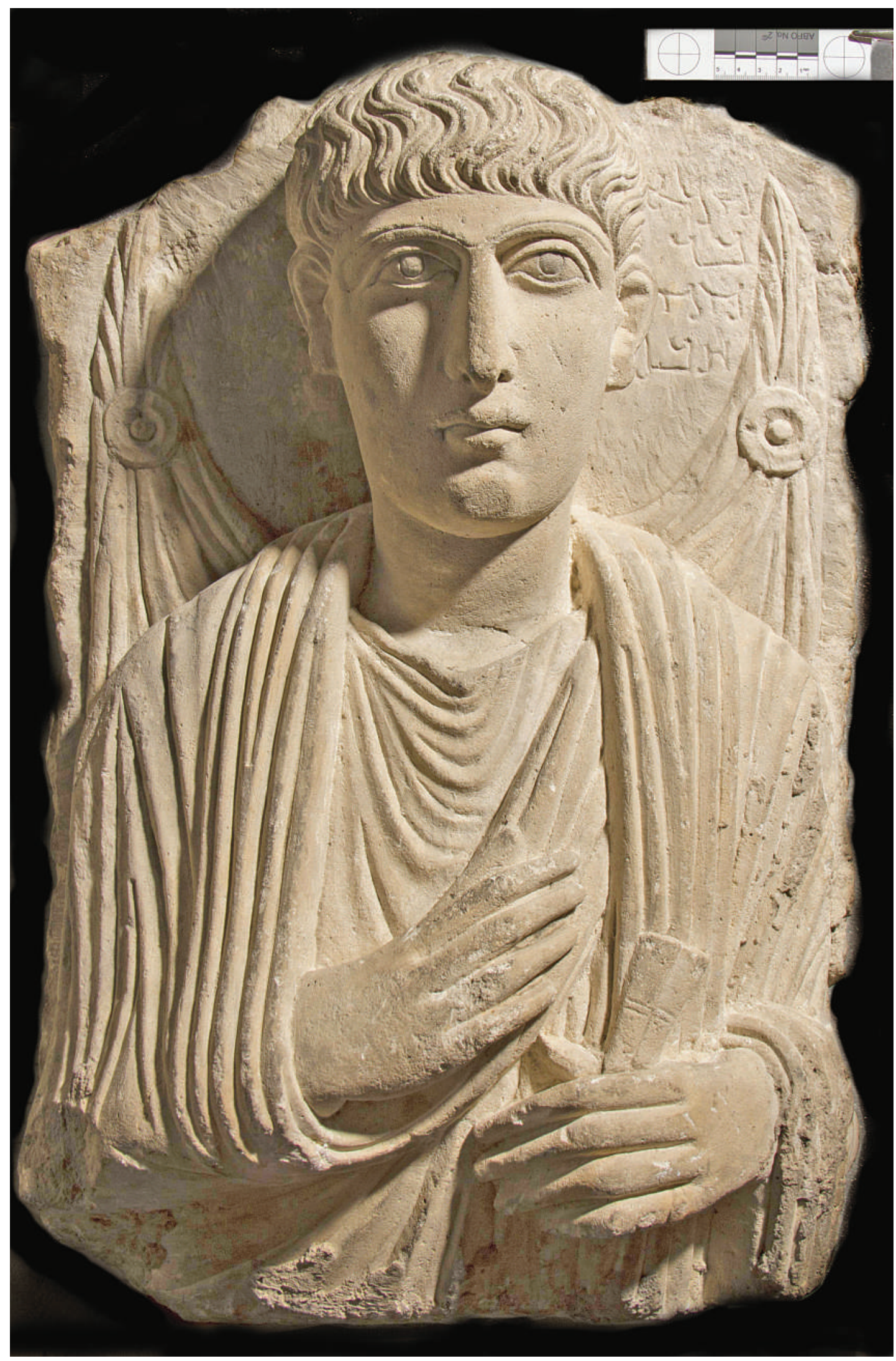

Fig. 1. HSM 1894.3.1, relief-bust of a youth, identified as Malē (Photo @ N. E. Greene and C. E. Bonesho) 


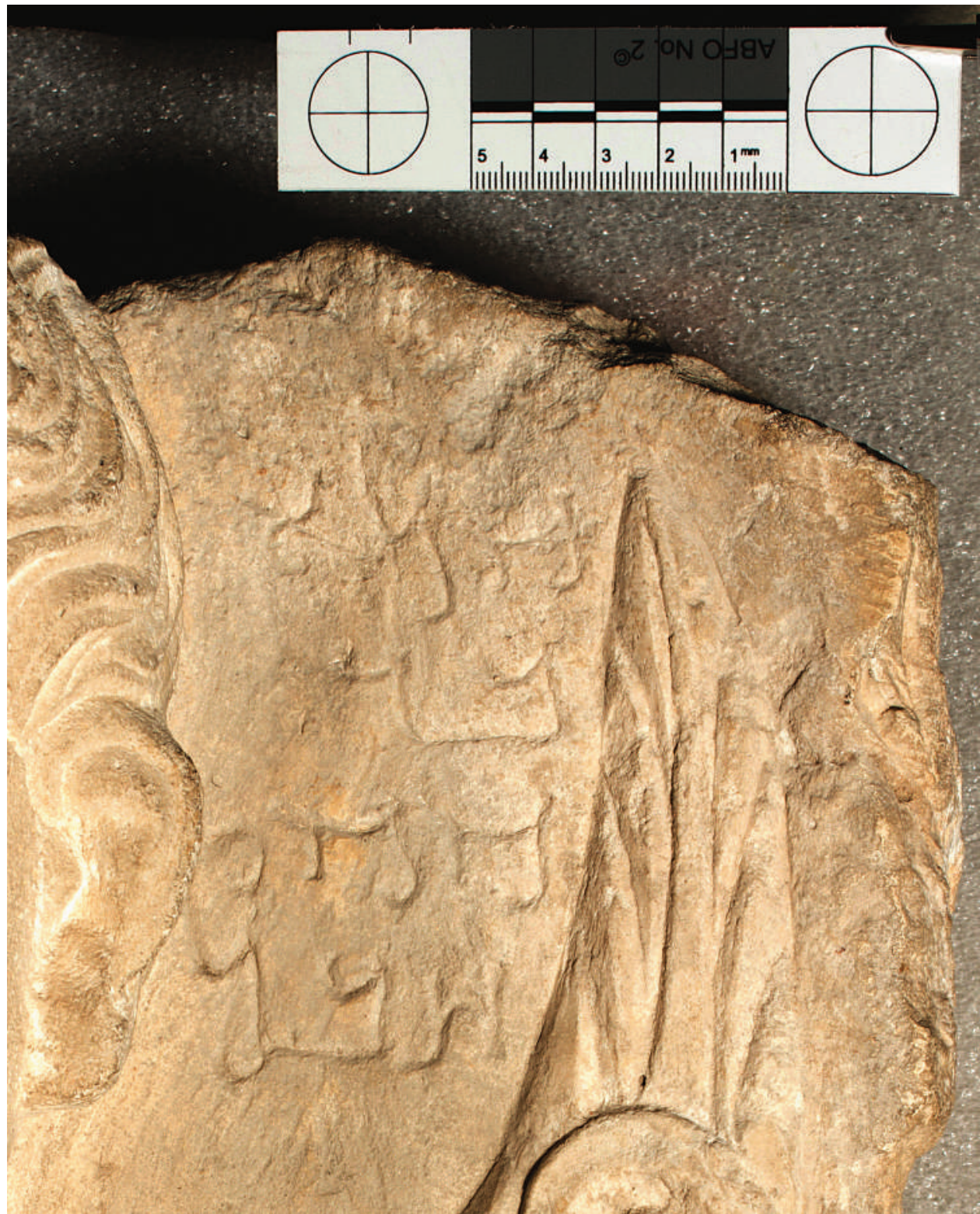

Fig. 2. HSM 1894.3.1, photo detail. (Photo @ N. E. Greene and C. E. Bonesho)

light of Latin Bassus is also possible. ${ }^{5}$ If the first letter is read nun, the name (Nesa') would be a hypocoristicon from the root ${ }^{\star} \mathrm{NS}$ '. In the Palmyrene corpus, the name is spelled $n s^{\prime}$ and $n s^{\prime}$ (Stark 1971: 100). ${ }^{6}$

\footnotetext{
${ }^{5}$ Jürgen Kurt Stark (1971: 77) considers this less likely. The name occurs in PAT 0048, PAT 0053, and PAT 0054, referring to the same person, and in PAT 0068 and PAT 1458, referring to two other individuals. On a tessera, PAT 2527: IOYAIO $\Sigma$ BA $\Sigma \Sigma O \Sigma$.

${ }^{6}$ Palmyrene graphemes $\langle\check{s}\rangle$ or $\langle s\rangle$ are used to express etymological /'s/ (Cantineau 1936a: 41-43). With samek, Nesa': PAT 0084, PAT 0096, PAT 0262, PAT 0405, PAT 0668, PAT 1354, PAT 1541, and PAT 1901. With shin, Neša': PAT 0018, PAT 0178, PAT 0254, PAT 0261, PAT 0324,
}

\section{HSM 1902.45.29: Relief-Bust of a Woman} (Museum Registration No. 2709) (Fig. 7)

\section{1. 'mtlt 'Amatallat,}

PAT 0345, PAT 0361, PAT 0503, PAT 0513, PAT 0563, PAT 0588, PAT 0630, PAT 0631, and PAT 0666-0667 (same person). Note for PAT 0668 the same genealogy, spelling of Nesa', and other examples. In the Tariff,

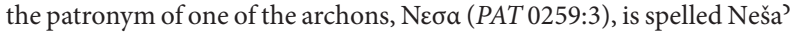
(PAT 0259:I 3). Note also for PAT 1541 and PAT 2726 the same genealogy: spelling Nesa' in the first and Neša' in the second case. Besides other Greek transcriptions, note in one case (PAT 0994) Latin Neses and Palmyrene Neša'. 


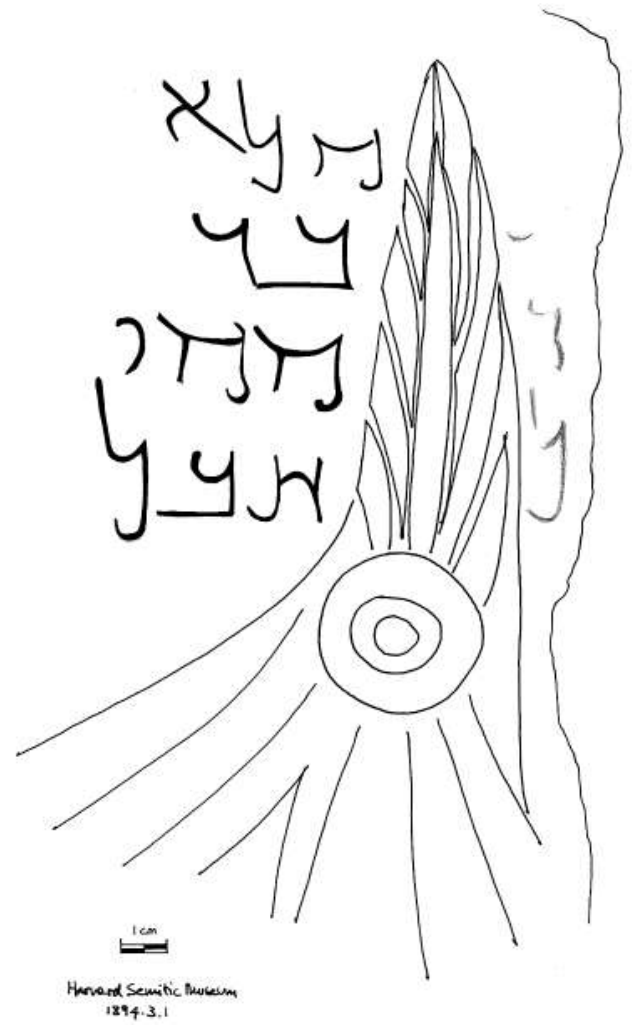

Fig. 3. HSM 1894.3.1. (Hand copy @ E. Cussini)

2. brt daughter of

3. šlm Šallum.

4. hbl Alas!

The third relief $(60 \times 36.8 \mathrm{~cm})$ depicts a woman named 'Amatallat, ('mtlt). The epitaph is carved to the left of her head in monumental style in four horizontal lines (Figs. 8, 9, detail of inscription). Like the first inscription, it is another standard epitaph that records the woman's name followed by her patronym and the exclamation $h b l$, "Alas!" The name 'Amatallat, "Maid of Allat" (Stark 1971: 70), is attested in three other inscriptions, where it identifies other women, as indicated by their variant patronyms. ${ }^{7}$ The hypocoristicon 'Amata' (' $m t^{\prime}$ ') is documented as well. ${ }^{8}$

7 PAT 0168: "Amatallat, daughter of Bareca"; PAT 0725: "Amatallat, daughter of Mezabbana"; and PAT 0970: "Amatallat, daughter of Haira". In addition, "Amatallat, daughter of [...]" (al-As'ad, Gawlikowski, and Yon 2012: no. 16); and "Amatallat, daughter of Hannibel" (al-As'ad, Gawlikowski, and Yon 2012: no. 58).

${ }^{8}$ PAT 0057:2 and PAT 0058:8, both mentioning "Julia Aurelia 'Amata', daughter of Bolhazay"; PAT 0070:2: "Amata', wife of Maloka"; and numerous other examples.
Her father's name may be analyzed as a hypocoristicon, perhaps of the well-attested masculine name Šalamallat, šlmlt (Stark 1971: 51). ${ }^{9}$ We can conclude this in light of his daughter's name, characterized by the theophoric element 'Allat. Other cases of a masculine truncated form šlm are rare: It occurs twice on tesserae. ${ }^{10}$ Another masculine name from the same root is Šalma', šlm', found in funerary ${ }^{11}$ and honorific inscriptions. ${ }^{12}$ Finally, the form šlmwy occurs in two epitaphs (PAT 0684: "[Her-] ta / daughter of 'Ogailu, [son of] Šalmuway"; and PAT 0692: "Šalmuway, son of Bonne"). ${ }^{13}$ More frequently, it occurs as a feminine name in the forms šlm (PAT 0093: "Šalam, daughter of 'Oga"), šlmy (found once in PAT 0576: "Šalmay"), and šlwm (e.g., PAT 0721: "Šalom, / daughter of / 'Aušay"). ${ }^{14}$

\section{The Busts and Their Art Historical Context By Maura K. Heyn}

\section{HSM 1894.3.1}

The first of the three sculptures in the Harvard Semitic Museum features a male depicted in high relief on a rectangular limestone plaque $(58 \times 41 \mathrm{~cm})($ see Fig. 1). The clean-shaven male wears a tunic and cloak, and appears before a curtain that is attached on either side by a circular pin with a knob-like object at its center. Two palm fronds extend above the circular pins. The significance of this curtain and the palm fronds, which do not appear behind the other two busts in this collection, is debated: The curtain may be shorthand for the interior of the tomb or for the funerary apparel. It might also symbolize the boundary between the world of the living and that of the dead. Its inclusion would appear to be random, though it may indicate that the person represented had already died by the time of commission

\footnotetext{
${ }^{9}$ Obviously, this is just a possibility.

${ }^{10}$ PAT 2104: "The sons of / 'A'alay, (son of) / Šalam"; and PAT 2184: "The sons of Šalam / the elder."

${ }^{11}$ E.g., PAT 0018: "Yarhibola', / son of Neša', / (son of) 'Oga', (son of) Šalma”,; PAT 0553: "'Oga', son of Šalma', (son of) [Šam] šigeram”; and PAT 0562: "'Oga' and Šalma', / sons of Šalma', son of Taime'."

12 PAT 0289: "Julius Aurelius Šalma”"; or PAT 0316: "Šalma', son of Maliku."

${ }^{13}$ The numerous examples of the form šlmn in funerary (PAT 0461), dedicatory (PAT 0345), and honorific inscriptions (PAT 1066) are theophorous names. The same applies to the feminine form šlmt (PAT 0095, PAT 0612, etc.). An interpretation of the theonyms is uncertain: They derived from Phoenician Šalman or, more likely, from Akkadian Šulman and Šulmanitu. Their cult originates from an Arabic context, and in Palmyra they were worshipped with other Arab deities (Hillers and Cussini 1996: 415 with references).

14 The form šlm in the last line of PAT 1251, a fragmentary epitaph, is the noun "peace" rather than a personal name (Cantineau 1936b: no. 98).
} 


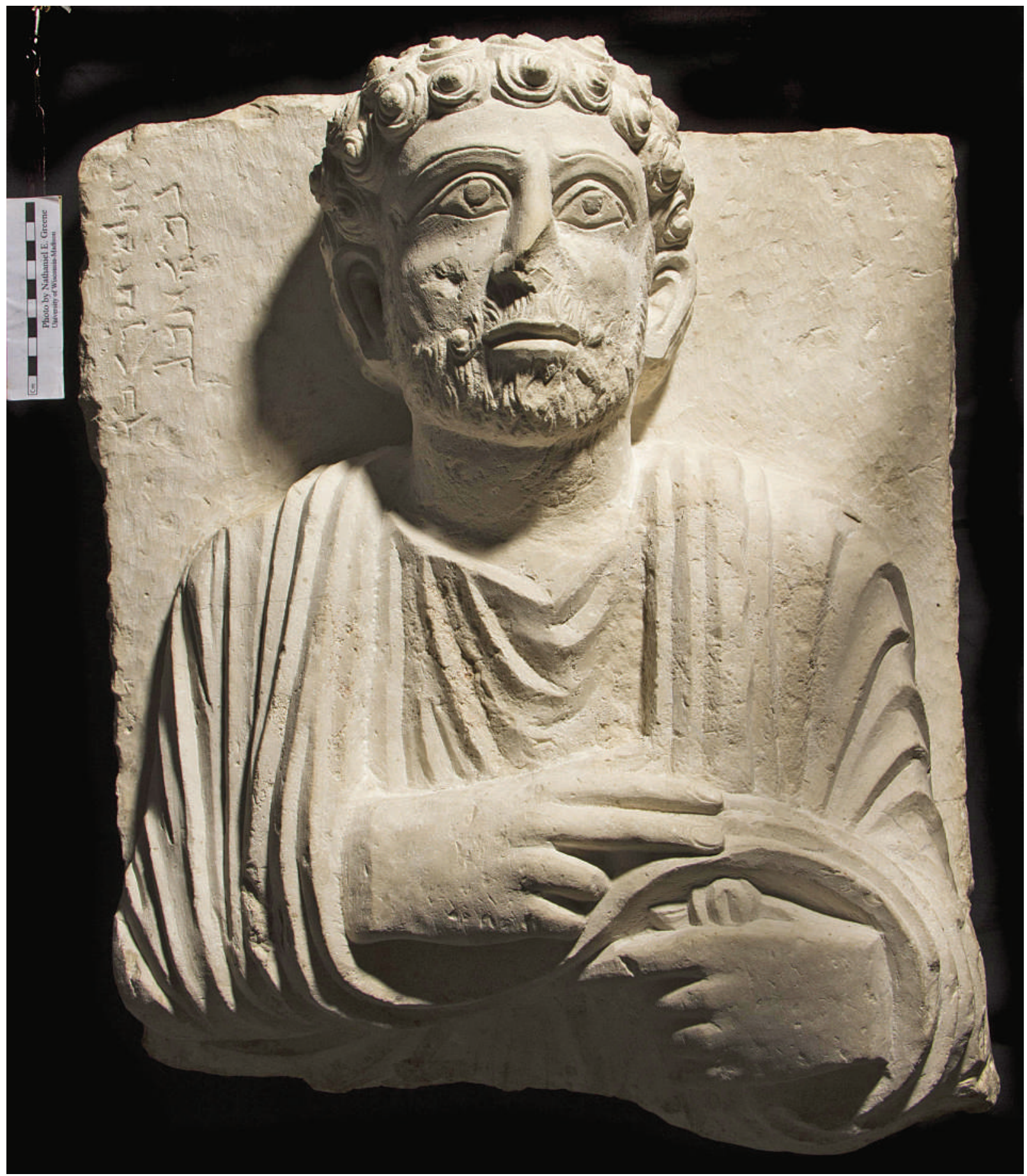

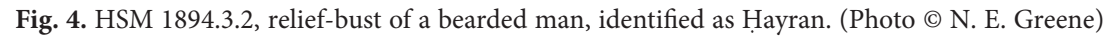

(Colledge 1976: 157). The palm fronds may symbolize victory over death (Dentzer-Feydy and Teixidor 1993: 76-77).

As is typical of Palmyrene male portraits, the draping of the deceased's cloak creates a sling around his right arm in an arrangement commonly seen in Roman funer- ary portraiture in the late 1 st century B.C.E. and early 1 st century C.E. (Kleiner 1977). This particular Palmyrene portrait differs a bit from the usual arrangement, however, with the cloak originating on his left side, draping down in the front to catch his right arm in the sling, coming back up to loop around his neck, falling back down 


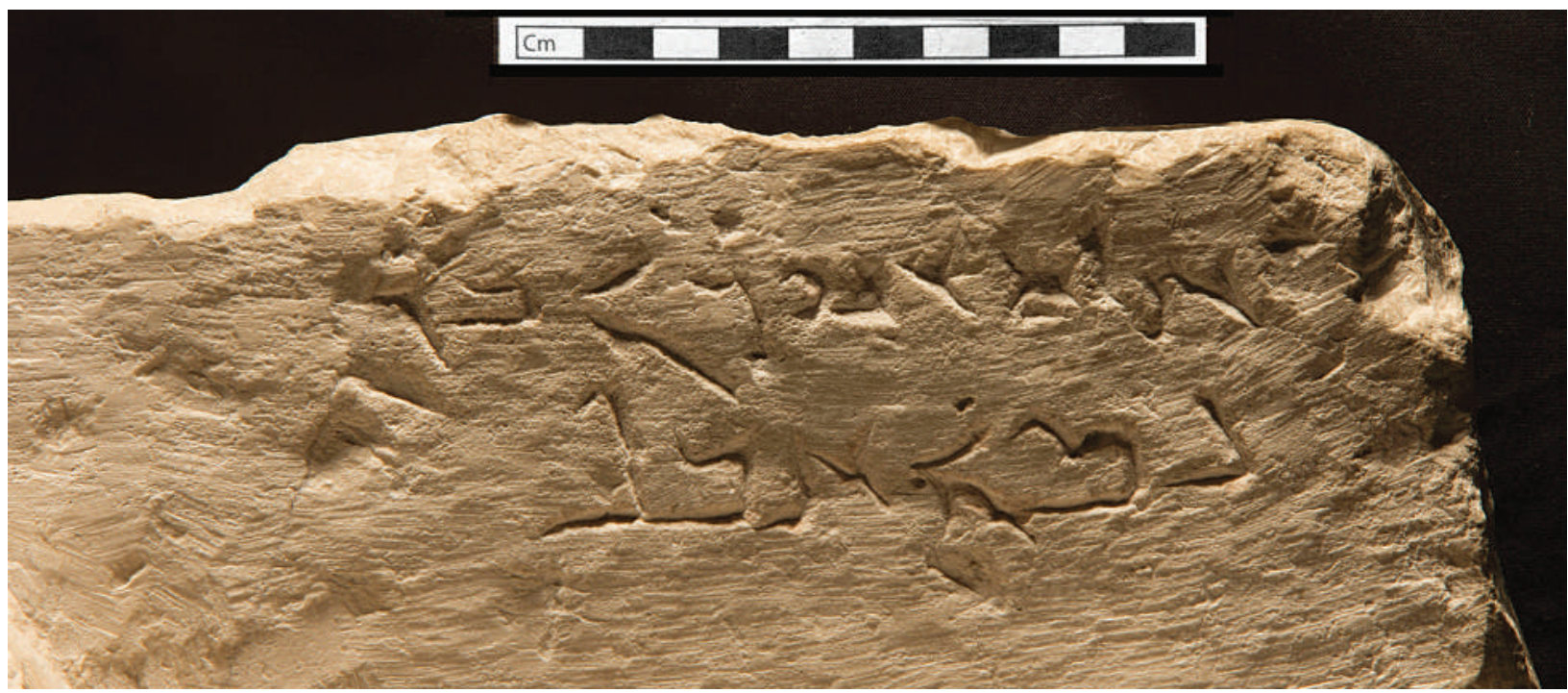

Fig. 5. HSM 1894.3.2, photo detail. (Photo @ N. E. Greene)

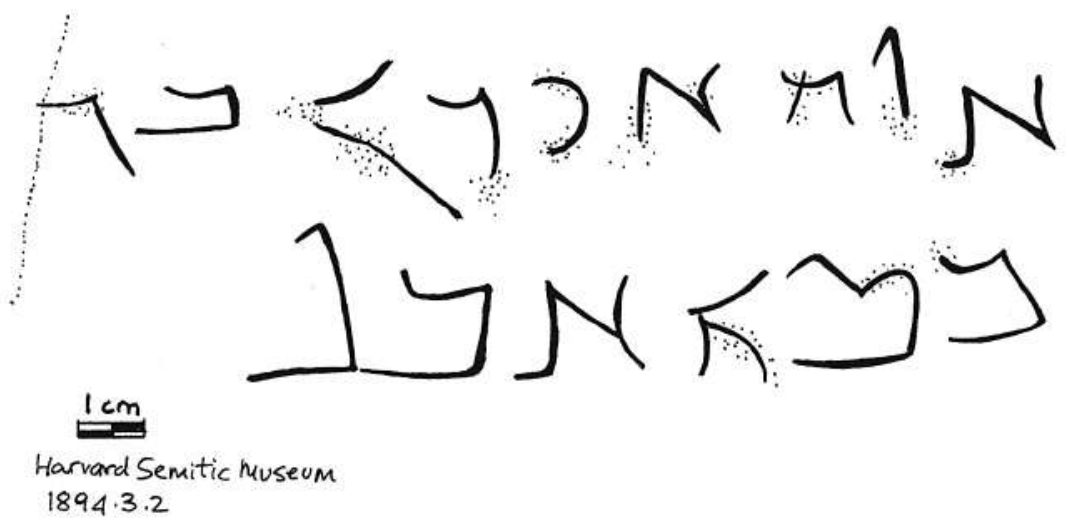

Fig. 6. HSM 1894.3.2. (Hand copy ๑ E. Cussini)

on his left side, and then encircling his left forearm. ${ }^{15}$ The deceased's right hand extends over the fold of the cloak, and in his left, also fully extended, he holds two book rolls. The book rolls, rendered here as rectangular sticks with two horizontal lines bisecting their visible portion, are a common attribute in Greco-Roman portraiture, though their significance is not easily determined (Colledge 1976: 68, 154). They could be an indication of literacy (and thus cultural refinement [Zanker 1993: 218]). Alternatively, in a funerary context such as that at Palmyra, the scrolls may represent the deed to the tomb (Ingholt 1928: 24; Ploug 1995: 47; Sokołowski 2014; see

${ }^{15}$ In Malcolm Colledge's classification of drapery arrangements, this would be \#9 (1976: 245-46). above). The deceased also wears a ring with a circular bezel on the little finger of his left hand. Rings such as this, worn on the little finger of the left hand and modeled on a Roman prototype, start to appear on Palmyrene male and female portraits in the middle of the 2 nd century C.E. (Colledge 1976: 152; Ploug 1995: 47 [citing also the discussion of rings in Mackay 1949: 169]; Dentzer-Feydy and Teixidor 1993: 74-75).

His hairstyle, brushed forward in wavy locks that curve slightly to the left with a straight hairline, became popular in Palmyra in the first half of the 2 nd century C.E. (Ploug 1995: 76). His eyebrows are rendered as simple incised lines and still retain some of the original color. This same color outlines his large eyes and darkens the iris, which is depicted by an engraved circle that touches the clearly 


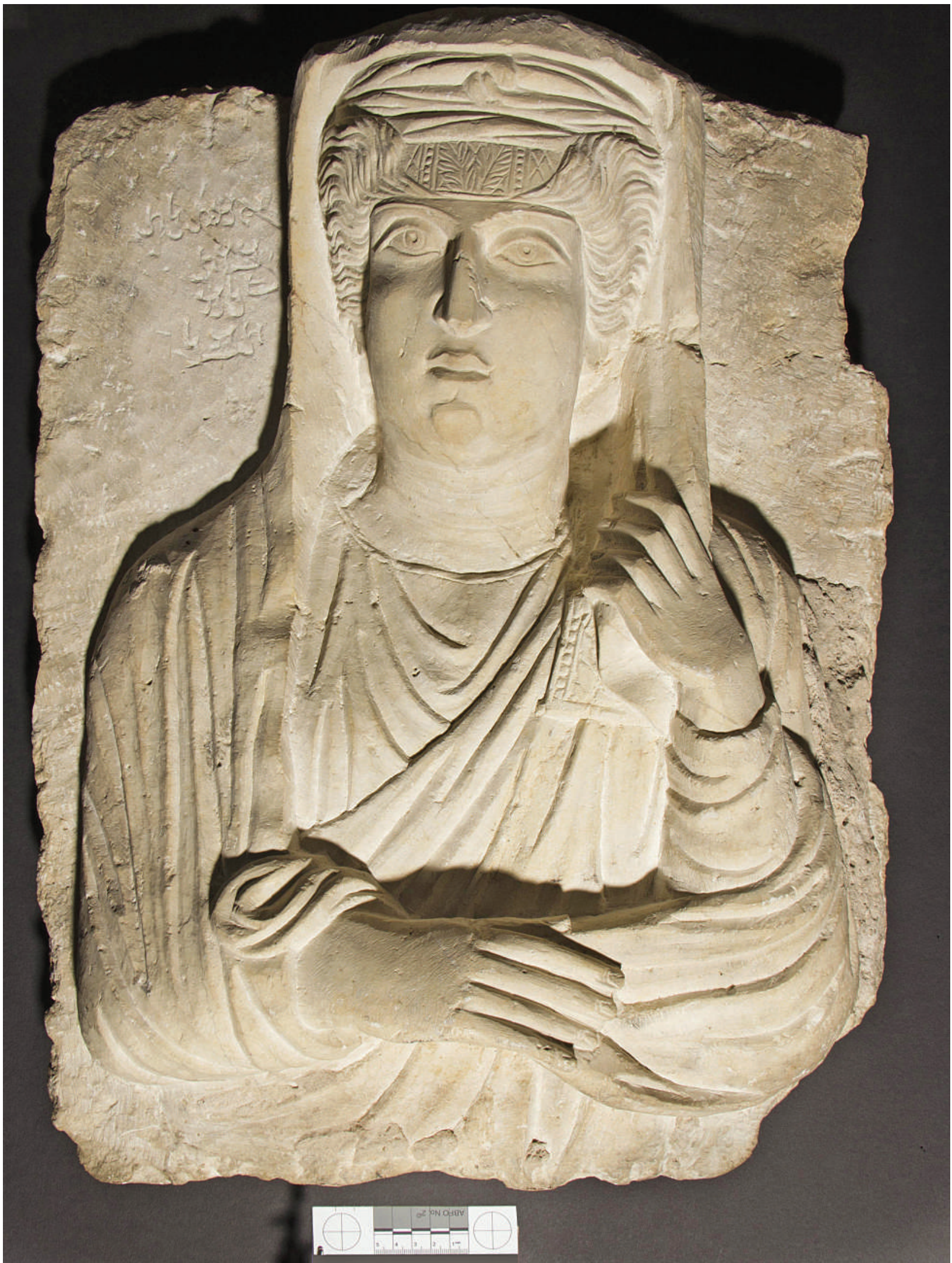

Fig. 7. HSM 1902.45.29, relief-bust of a woman, identified as 'Amatallat. (Photo @ N. E. Greene and C. E. Bonesho) 


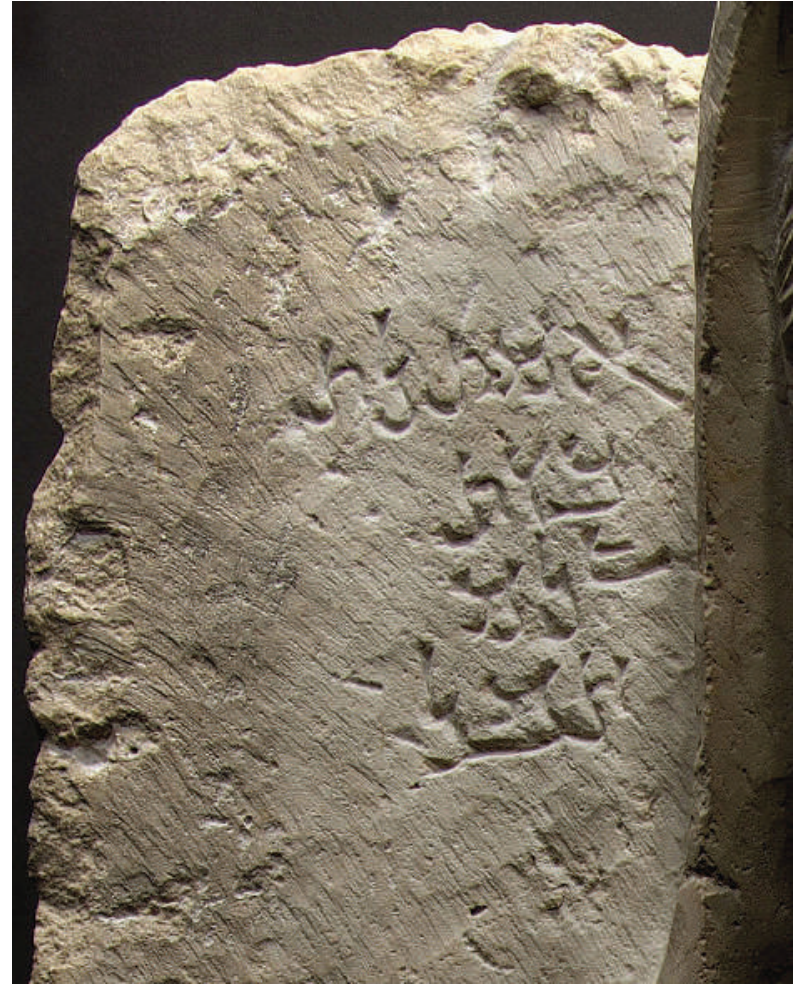

Fig. 8. HSM 1902.45.29, photo detail. (Photo (C) N. E. Greene and C. E. Bonesho)

defined upper eyelid. The pupil of his eye is not indicated. His nose is long and straight, his mouth is small, and his flat chin juts out a bit. His ears also protrude from the sides of his head. The skin of his face and neck is smooth.

The increasing popularity of beards in Palmyrene male portraiture after the mid-2nd century c.E. would suggest that this clean-shaven portrait predates that transition (Colledge 1976: 248). However, clean-shaven men (who are not priests) do continue to appear after 150 C.E., and this male's hairstyle and the manner in which his eye is rendered (with an engraved circle for the iris and the missing pupil) are more typical of relief-busts produced between 150 and 175 C.E. (Colledge 1976: 248; Ploug 1995: 126-27). In addition, the style in which the drapery is rendered is much more characteristic of the second half of the 2 nd century. In view of these stylistic factors, it seems likely that the portrait was produced toward the end of the period dating from 150 to 175 C.E. (Colledge 1976: 248, group II). ${ }^{16}$

${ }^{16}$ A comparable bust in the Ny Carlsberg Glyptotek is dated 150170 C.E.; toward the end of the period, cf. I.N. $1052=$ PAT 0749 (Ploug 1995: 128-30); and for a bust dated 170-190 C.E., cf. I.N. 1040 (Ploug 1995: 130-32). See also Sadurska and Bounni 1994: no. 64 (= PAT 1032), which the authors dated $160-190$ C.E.

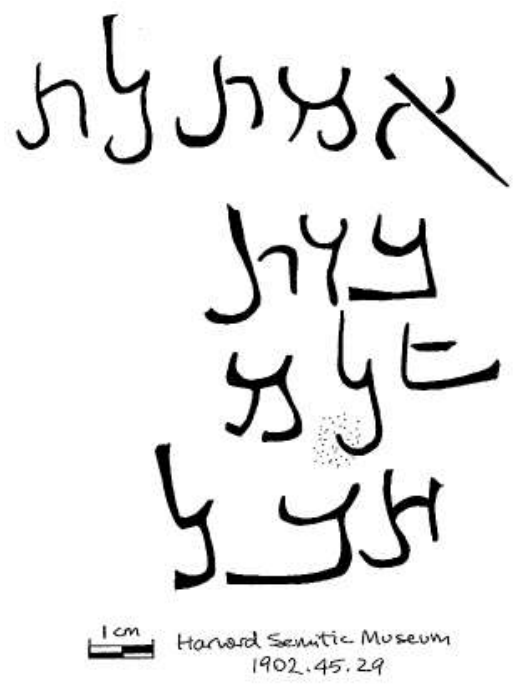

Fig. 9. HSM 1902.45.29. (Hand copy @ E. Cussini)

\section{HSM 1894.3.2}

The second bust is slightly smaller $(49 \times 43 \mathrm{~cm})$ than the first. This bearded male, identified in the inscription above his right shoulder, wears a tunic and cloak (see Fig. 4). Like the draping of the first bust, the draping of this figure's cloak is also somewhat unusual. It is perhaps without parallel: Rather than returning over his left shoulder after catching his arm in the sling arrangement, the cloak seems to be drawn directly from the sling under his right arm across his torso to his left, where it is wrapped around his left wrist. The man holds only a loop of the cloak in his left hand; this is a more typical aspect of Palmyrene portraiture than is the peculiar draping of the cloak. He holds no other attributes and wears no rings. The gestures of his hands are interesting: With his right hand, emerging from the sling of the cloak, he extends the index and middle fingers; on his left side, he holds out the index finger only. The significance of these gestures is unclear, but perhaps they functioned to draw attention to the portrait in the tomb (Heyn 2010: 640).

His hair is rendered with several rows of snail-shell curls; his eyebrows are represented with incised, curving lines; and his eyes are overly large. The irises, which give the impression of gazing upward, are depicted with an engraved circle and retain some of their original color (more so in his left eye than his right). Continuing down the face, the nose is damaged, but the luxuriant moustache and beard have survived well. The edges of the moustache curve up jauntily in the "handlebar" style, ${ }^{17}$

17 Similar handlebar moustaches are seen on other male busts, most of which date to the first third of the 3rd century c.E.: a male bust in the 
and the impression of a luxuriant beard is created with striations on triangular-shaped tufts of hair. The lips are thin and turn down slightly. Although the upward-gazing eyes are typical for portraiture created between 150 and 200 C.E. (Colledge 1976: 69), the stylistic evidence as a whole points clearly to a production date between 200 and 230 C.E. The curved groove for the eyebrows, the snail-shell curls, the manner in which the beard is carved, and the loop of cloak held in the left hand are all typical features of male portraits from the first third of the 3 rd century (Colledge 1976: 251).

\section{HSM 1902.45.29}

The third bust $(60 \times 36.8 \mathrm{~cm})$ depicts a female (see Fig. 7). The clothing worn by the deceased is typical of women in Palmyra: She wears a long-sleeved tunic and cloak, with a trapezoidal brooch holding her cloak in place on her left shoulder. The veil on her head extends down on both sides of her body, loops around her right forearm, and is drawn around her left arm by means of an extended right hand. She holds no attributes. Her left hand reaches up to hold the veil at neck height. Underneath the veil on her head, the woman wears a turban, and below this turban across her forehead she wears a diadem. The central panel of the diadem-which is framed by the woman's hair, diagonally brushed outward on both sides of her face-features two acanthus leaves. The lobes of her ears, unadorned by earrings, are visible beneath the outwardly brushed hair at the sides of her face.

The woman's eyebrows are rendered with double incised lines; the iris of her large eyes is depicted with an engraved circle, and the pupil within by means of a drillhole. This use of a drill-hole to represent the pupil begins already during the mid-2nd century C.E. and continues throughout the 3rd century (Ploug 1995: 126-27). The woman's nose is straight, and her mouth rather small, with an upside-down $\mathrm{V}$-shaped notch underneath the bottom lip and just above her chin. The chin is flat and juts out prominently. Three wrinkles are represented by three parallel and slightly curving grooves on her neck.

Perhaps the most noteworthy feature of this female relief portrait is the lack of jewelry. Palmyrene women are well known for their elaborate displays of jewelry in their portraits: earrings, necklaces, bracelets, rings, etc. This paucity of jewelry is particularly surprising because both the raised position of her left arm, with her hand grasping the veil at neck height, and the extended position of her right hand, pulling the veil across her torso,

J. Paul Getty Museum, Malibu (88.AA.50 = PAT 2714); four male busts in Palmyra (Sadurska and Bounni 1994: no. $58=P A T$ 1027, no. $176=$ PAT 1857, no. $177=$ PAT 1858, no. $183=$ PAT 1861); and a bust in the Ny Carlsberg Glyptotek (I.N. $1046=$ PAT 0637). are typical for female portraits created in the 3rd century C.E. (Colledge 1976: 262), when it was also popular to wear abundant amounts of jewelry. For whatever reason, certain women from this period, including this one in the Harvard Semitic Museum, are depicted relatively unadorned. Other stylistic features corroborate the dating of this bust to the 3rd century, but the retention of certain features from the earlier period suggests a date very early in the century (ca. 200 C.E.). For example, the long-sleeved tunic is popular during the 3rd century (Colledge 1976: 262), but the trapezoidal brooch is a holdover from the second half of the previous century, with most women in the 3rd century opting for a circular style (Colledge 1976: 71). Comparable busts, either with similar hairstyles ${ }^{18}$ or with analogous jutting chins and neck wrinkles, ${ }^{19}$ date primarily to the late 2 nd century and early 3 rd century C.E.

\section{History of Possession 20 \\ By Jeremy M. Hutton, Nathaniel E. Greene, and Catherine E. Bonesho}

As indicated by their accession numbers, two of the three busts (HSM 1894.3.1, HSM 1894.3.2) were acquired by David Gordon Lyon on behalf of the Harvard Semitic Museum in 1894. The museum's records of these two funerary busts extend back to December 26, 1893. On that date, General Charles G. Loring, then executive of Boston's Museum of Fine Arts, drafted a letter (addressed "My dear Sir," presumably in reference to Lyon) calling the addressee's attention to "two heads from Syria with Semitic inscriptions." The author of the letter and his addressee had previously communicated about

\footnotetext{
${ }^{18}$ For a description of similar hair, see Ploug 1995: 147, 149 on $\mathrm{Ny}$ Carlsberg Glyptotek I.N. 1067, dated 170-190 C.E.

19 For similar "jutting" chin, wrinkles on neck, and eyes, see Ny Carlsberg Glyptotek I.N. 1062 = PAT 0850 (Ploug 1995: 142-45). The jutting chin is also seen on I.N. 1067 (Ploug 1995: 147-48) and I.N. 1060 = PAT 0750 (Ploug 1995: 149-50). See also several comparable portraits from Palmyra (Sadurska and Bounni 1994: no. 36, fig. $178=$ PAT 2659; no. 84, fig. $179=$ PAT 1051).

${ }^{20}$ During the course of preparations for a research trip to the eastern seaboard in 2013, Hutton, Greene, and Bonesho were alerted to the presence of three funerary busts through personal communication with the staff of the Harvard Semitic Museum (Adam J. Aja, pers. comm., January 8, 2013); The University of Wisconsin team received permission from the Harvard Semitic Museum to perform research on these inscriptions. Greene and Bonesho traveled to Cambridge, MA, during June of 2013. They photographed the inscriptions on Harvard's campus on June 25-26 using reflectance transformation imaging. During that period, they were granted access to all of the files on the busts (Joseph Greene, pers. comm., June 25, 2013, August 12, 2013). It is with deep thanks that the authors cite Greene's communications, since he has been especially helpful in tracking down the pertinent records and in reconstructing the sequence of events whereby these inscriptions came into the possession of the Harvard Semitic Museum.
} 
these artifacts, and the former had sent squeezes of the inscriptions. According to the letter, "[t]he owner fixes no price[,] and if you wish them[,] you could have them almost at your own [named price]." The cryptic final paragraph of the letter states, "[y]ou will find them here just outside of my door, but I trust you will let me see you when you come." Although other interpretations are possible, the author's use of the Museum of Fine Arts' letterhead in combination with his reference to his door would suggest that the artifacts were already in Boston. Evidently, negotiations for the bust were concluded by April 30 of the following year, when Loring wrote to the Harvard Semitic Museum that "[t]he two heads ... will go out by express to-day or to-morrow." A third letter from Loring, in significantly less formal (and consequently more difficult) handwriting, provides the final written record of this correspondence, conveying the former owner's information concerning the funerary busts' purported provenance. Once again, Loring addressed the unnamed Harvard Semitic Museum official:

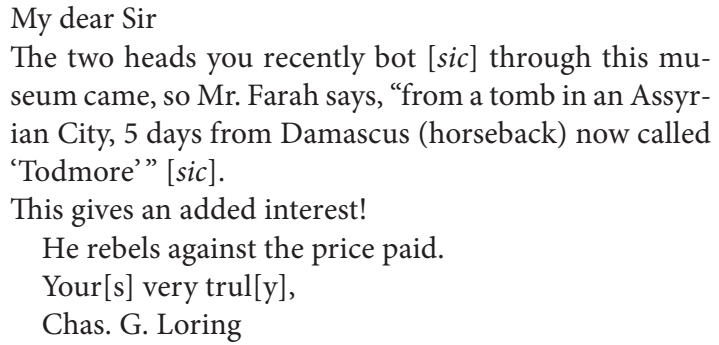

According to the Harvard Semitic Museum's records, the "Mr. Farah" mentioned here was Alexander Farah of Tyre (perhaps a professional dealer of antiquities at the time?). Although this meager record of correspondence hardly validates these inscriptions' authenticity, it does provide some record of their whereabouts during the year prior to their accession into the collection of the Harvard Semitic Museum.

The third funerary bust (HSM 1902.45.29) was acquired eight years later from Georges Nassan, a merchant based in Damascus. An elegant two-page receipt from “G. Nassan \& C.ie," dated May 1, 1902, lists several purchases, all of which can be identified by the registration numbers secondarily added in a different hand in the left margin. The last piece of merchandise listed is a "Petite [statue ancienne de Palmire]," which sold for 125.00 francs; the registration number identifies this as the artifact bearing our third funerary inscription. On the same receipt is listed a fourth inscribed bust ("Grand statue [ancien] de Palmire," 225.00 francs). This fourth bust entered the Harvard Semitic Museum's collection under the accession number 1902.45.28 [= PAT 2721]) but has subsequently been traded to the Harvard Uni- versity Art Museums as part of a three-way deal with the Stanford University Art Museum (the Cantor Center for the Visual Arts), which "brought a portion of Stanford's Cesnola Cyprus Collection to the [Harvard] Semitic Museum" (J. Greene, pers. comm., August 12, 2013). That fourth bust currently resides in the Harvard University Art Museums' Arthur M. Sackler Museum. This paperwork attests to the busts' presence in the United States by 1902 and offers an unconfirmable and unfortunately vague attestation to the reliefs' original provenance.

\section{Palaeographic Notes}

By Eleonora Cussini

In January 1996, I copied the inscriptions and studied the Harvard Semitic Museum reliefs as part of an ongoing project in connection with the research conducted with Delbert R. Hillers for Palmyrene Aramaic Texts $(P A T)$. When possible, we felt it necessary to examine directly the inscriptions included in our volume. As a result of several research trips made to museums in the United States, Europe, and the Near East, I inserted into our research files collation notes and corrections or, as was the case with the Harvard Semitic Museum reliefs, the Aramaic text and English translation of the three unpublished inscriptions. ${ }^{21}$ Since PAT had already been completed, we decided to keep track of new inscriptions published by others and give them progressive PAT numbers in our private files. The same applied to new inscriptions found in the course of field trips. ${ }^{22}$

As I went through the Harvard Semitic Museum's acquisition records, made available during my visit to the museum, I realized it was impossible, based on the available information, to track the tomb or tombs from which the three reliefs originated. As seen above, the bust of Malē and that of Hayran had been bought in 1894 in Tyre, from Farah, while the bust of 'Amatallat was purchased eight years later in Damascus from Nassan, together with another funerary relief (PAT 2721). This last relief bears the epitaph of another Malē, son of Maliku, and of his son, Maliku. In this case, as in the previous ones, one cannot identify the tomb. ${ }^{23}$ It is not possible to

\footnotetext{
${ }^{21}$ After the publication of PAT, we updated our joint research files (C Hillers/Cussini) by creating a digital version of errata and adding new bibliographic references and a complete English translation of all the Palmyrene epigraphs; we also added other published texts not included in PAT and unpublished epigraphs resulting from my museum work. Our joint work was halted by Professor Hillers's untimely passing in September 1999, while I continued my research at the Università Ca' Foscari Venezia, Italy.

22 The Harvard Semitic Museum inscriptions were entered in the Hillers/Cussini research files as PAT 2846 (HSM 1894.3.1); PAT 2847 (HSM 1894.3.2); and PAT 2848 (HSM 1902.45.29).

23 The genealogy of this Malē, son of Maliku (PAT 2721), cannot be connected to 'Amatallat's family. With regard to PAT 2721, it may be
} 
find out whether Nassan traded two artifacts originating from the same or two different tombs. The same holds true for the two reliefs sold by Farah. As in several other cases, prosopographic reconstruction is hindered by the lack of additional distinctive features, such as unique names, nicknames, or professions. This, alongside the brevity of the three inscriptions, which record two generations only, make it difficult to connect them to other family groups.

The first (HSM 1894.3.1) and the third (HSM 1902.45.29) epitaphs show different examples of Palmyrene Aramaic monumental or formal script, while the second one (HSM 1894.3.2) is written in another script generally referred to as "cursive" or, following Jacqueline Pirenne (1963), "Syro-Palmyrene" script. Cursive style or, rather, different cursive styles or handwritings were mainly used on perishable writing material (Naveh 1975; Cussini in press). There are, however, examples of cursive scripts on stone, as shown by various inscriptions, including funerary epitaphs comparable to the one discussed here. In this as in other known cases, the inscription is written in vertical lines. ${ }^{24}$ Verticality, however, was a functional feature determined by the available epigraphic surface and not by the type of script employed. There are cursive epitaphs written in horizontal lines and examples of epitaphs in monumental or mixed formal and cursive script written in horizontal and vertical lines (Naveh 1975; Cussini in press).

On the first relief, beyond the palm frond, there are light traces of another inscription (see Fig. 3). This was perhaps the epitaph of a relative who was originally depicted next to Malē. Only faint remains of it may be detected on the worn surface: On the first line, halfway between the first and the second line of Malës epitaph, there is an oblique stroke after the break (the remains of a he?), followed by two letters. One line below is a dalet or, more likely a resh, perhaps the last letter of $b r$ "son of" (?). Below it, there is a lamed (?), possibly the ending of $h b l$ "Alas!" Reconstructing this other inscription is impossible.

\section{The Script of HSM 1894.3.1 and HSM 1902.45.29}

Inscriptions HSM 1894.3.1 (Malë's epitaph) and HSM 1902.45.29 ('Amatallat's epitaph) are both written in a monumental script. Some differences, however, may be observed between the two. Palaeographic comparison

connected to PAT 0354 (191 C.E.) and PAT 0360 (207 C.E.), two religious dedications. Five generations of that family may be reconstructed, including Maliku's sons, Wahaba (PAT 0354) and Malē (PAT 0360); Malës wife, Makki; and her father, 'Oga' (PAT 0360).

${ }^{24}$ For Palmyrene and contemporary vertical inscriptions on stone and other writing material, see Naveh 1976; 2009: 230-32. may be conducted on six letters out of a total of ten available examples (Fig. 10). Overall, 'Amatallat's epitaph (HSM 1902.45.29), which displays a wider palaeographic specimen, shows more formal and elegant features, especially illustrated by the shape of khet, mem, and resh.

Aleph. In the two inscriptions, we find something close to the regular shape of the Palmyrene monumental aleph. In Malës epitaph (HSM 1894.3.1), it is carved higher than the rest of the line; in both inscriptions, the oblique stroke is elongated, as in other monumental-style inscriptions (e.g., PAT 0482, tomb foundation text [95 c.E.]; PAT 0544, epitaph on a relief, etc.). This feature-like other examples of prolonged strokes or ligatures one sees in other Palmyrene writing specimens on stone-seems to be influenced by the practice of writing in cursive on perishable writing surfaces by means of an inked stylus.

Bet. There are four examples of bet, two in each inscription. As is the case with other letters, the specimens in Malē's epitaph are slightly taller than the two in 'Amatallat's. The first bet in line 2 of Malë's has a longer bottom horizontal stroke, connected to the vertical stroke of the following resh. In 'Amatallat's epitaph, the bet in line 4 has a longer bottom stroke and a bigger head.

Khet. The example in Malè's epitaph is squared in shape and differs from the rounded one in 'Amatallat's inscription. The latter has a shorter right vertical stroke and a longer left stroke that is tilted inward. With regard to this letter, too, Malē's example is taller and wider.

Yod. There is one example in Malës epitaph. It is not raised to the top but carved on the same imaginary line with the other letters. It has the shape of a comma and has almost the same dimensions as the other letters.

Lamed. Five examples are preserved. Those in Malës inscription are taller (especially that in line 4, which extends below the line) than the three in 'Amatallat's epitaph and do not display the same sinuousness and elegance. A third possible example on Malës relief (beyond the palm frond) pertains to another epitaph and is very faded.

Mem. Each inscription has two examples. Those in Malës epitaph are squared, wider, and taller than those in 'Amatallat's inscription. These last examples are characterized by rounder features and inwardly tilted bottom strokes. These features, as noted above with regard to khet, well illustrate the slight differences in style displayed by the two inscriptions written in monumental style.

Qoph. There is one specimen in Malē's inscription. It is a monumental-style qoph and very closely resembles the mem found next to it, to the point of appearing almost identical. In the Palmyrene script, mem and qoph are similar, albeit not as close in shape as here. Monumental mem has a short, concave top stroke (e.g., PAT 0594, epitaph on a stone tablet), whereas qoph displays a longer horizontal top stroke and shorter vertical strokes 


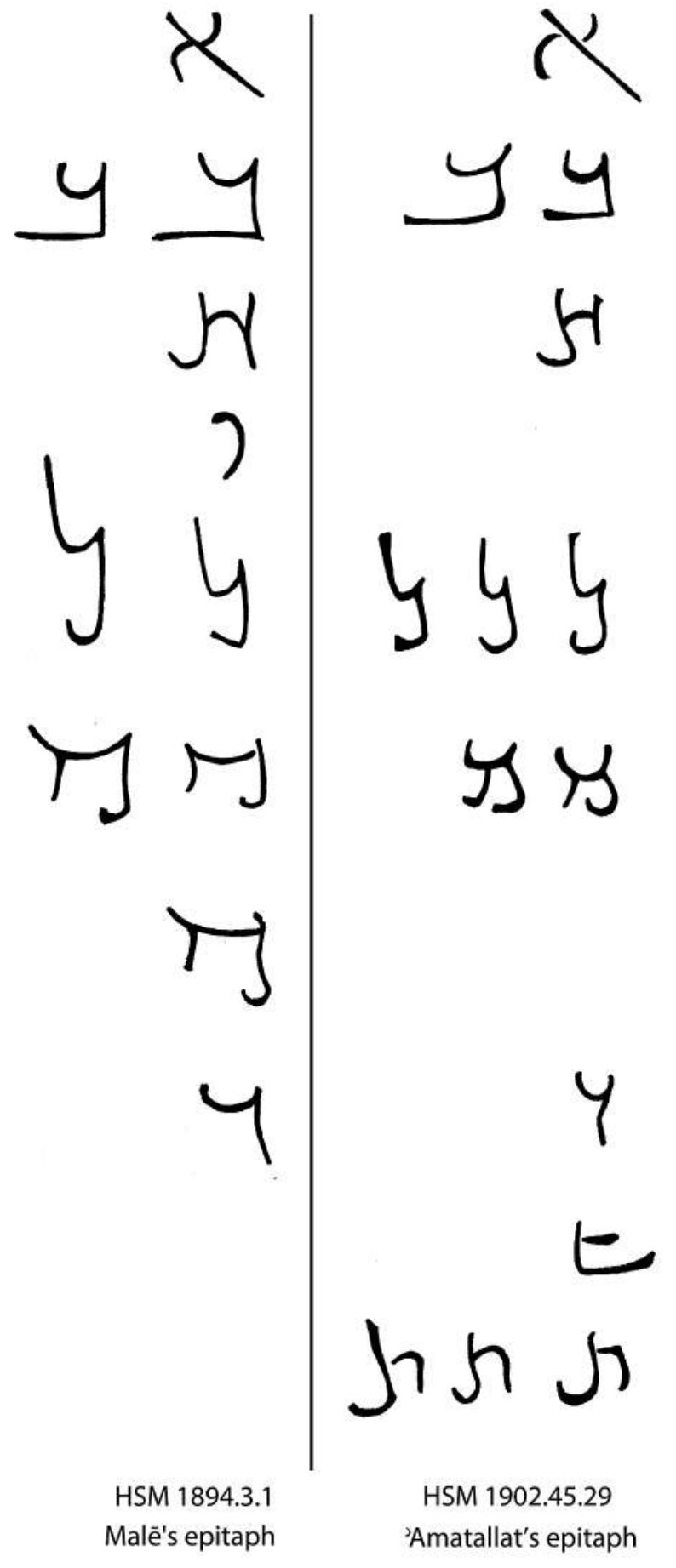

Fig. 10. Palaeographic chart: HSM 1894.3.1 (left); and HSM 1902.45.29 (right). (@ E. Cussini)

or legs (e.g., PAT 0318, dedicatory text on an altar [55 C.E.]). In Malē's epitaph, as in other examples of monumental qoph, the horizontal top stroke is just slightly longer than that of mem.
Resh. There is one example of resh in each epitaph. In addition to the smaller size and rounder shape, the one in 'Amatallat's epitaph displays a more formal character with a two-segment pointed vertical stroke (this Palmyrene monumental feature is less marked in the other epitaph). The top diacritic dot, which occasionally marks resh as opposed to dalet, is not indicated. There is possibly another partly preserved example of resh on Malës relief, beyond the palm frond.

Shin. There is one example in 'Amatallat's inscription. It is raised above the line, the right (here bottom) and middle strokes are horizontal or almost horizontal (the bottom stroke slightly rises to the right) and not oblique as in monumental-style specimens (e.g., PAT 0332, dedicatory text on an altar [114 C.E.]; PAT 0545, epitaph on a funerary relief), while the left stroke is vertical.

Tav. There are three monumental examples in 'Amatallat's inscription. The third specimen, in line 2, has a bigger left stroke than the two examples in line 1.

\section{The Script of HSM 1834.3.2}

The second relief, Hayran's epitaph (HSM 1894.3.2), is written in cursive script. Ten letters are preserved (Fig. 11; see also Fig. 6): three of them-aleph, lamed, and nunare particularly important because, in the cursive script (here and in other Palmyrene inscriptions on stone), they differ significantly in shape from the formal-style shapes examined above. Other letters that are also characterized by distinctive cursive shapes-for example, tav (with a loop to the left, or, as we would expect here, as a zigzag tav) or flat ayin-are not preserved in this inscription. ${ }^{25}$

Aleph. This letter differs from the monumental examples, including those in the other two inscriptions discussed herein. It consists of two short bottom strokes (one oblique to the right, a vertical to the left) and a top oblique right-to-left stroke. Specimens of this type of aleph may be found in other cursive-style inscriptionsfor example, PAT 0738 and PAT 0773 (Klugkist 1983: $59-60){ }^{26}$

Bet. There are two (or perhaps three) examples. The first in line $1(b r)$ is a cursive-style bet. It is squared and short, the top part almost entirely horizontal with an upward end. The second specimen at the end of line 2 $(h b l)$ is taller, as are all the other letters in that line. It is a monumental-style bet, marked by a more defined top part: a right-to-left oblique stroke with an almost vertical short stroke to the left. The other (possible) specimen, at the beginning of line 2, is debated (Fig. 11: Bet, second

\footnotetext{
${ }^{25}$ For examples of cursive-style tavs, marked by a left loop as in Old Syriac script, see Cussini in Meischner and Cussini 2004: esp. 103, fig. 5.

26 On PAT 0738, see Greene, Heyn, and Hutton 2012.
} 


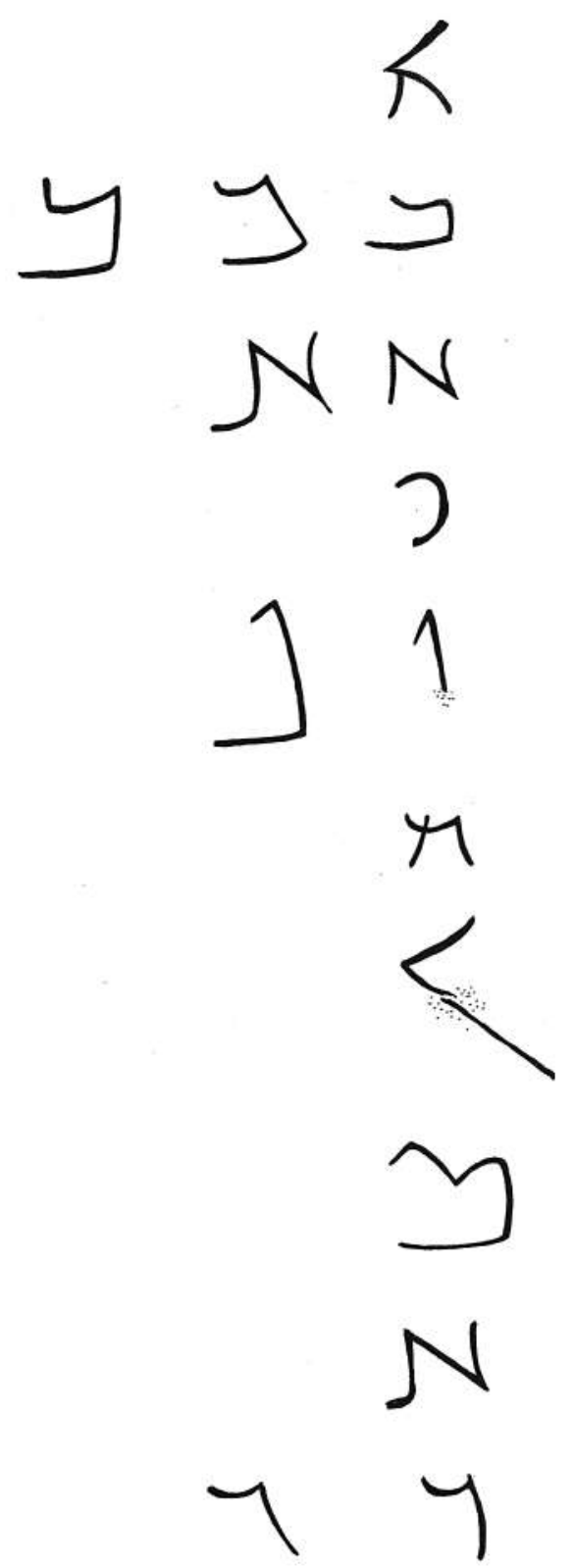

Fig. 11. Palaeographic chart: HSM 1894.3.2. (@ E. Cussini)

example). It is read as nun by Hutton, Greene, and Bonesho, who interpret the slightly rounded top part of bet "as a pock mark connected to the top of the vertical stroke by a curving groove." They consider it a nun, especially in light of the stance of the vertical stroke. ${ }^{27}$ Differences

27 Stance, however, does not seem a decisive argument when considering the overall features of this inscription; note, e.g., the different stance of resh in the same line: hyrn and br. in stance and shape may be observed in the two certain specimens of bet, which also vary in terms of dimensions. ${ }^{28}$ The stone presents small marks not related to the carving of this and other letters. Direct examination of the stone and photographs, however, shows the presence of a head, compatible with the shape of bet. As seen above, both readings of $b s^{\prime}$ and $n s^{\prime}$ are plausible in terms of Palmyrene onomastics.

Khet. There are two cursive-style examples. They both show a left concave vertical stroke, an oblique stroke, and a vertical stroke to the right, resembling an uppercase $\mathrm{N}$ (cf. tsade below). This shape is widely attested in cursivestyle epitaphs (e.g., PAT 0803) on funerary reliefs and in numerous other examples.

Yod. There is one example, rounded, as in Malës epitaph.

Lamed. There are two cases. They both display the pointed-top cursive shape. The example in line 1 is partly damaged, and the bottom horizontal stroke is not visible.

Mem. There is one example. The left stroke (in formalstyle specimens, usually carved to the right end of the top bar) here crosses the top bar, as in earlier Aramaic shapes.

Nun. A backward-head nun marks the end of Hayran's name. This type of final nun also occurs in formal-style examples (e.g., PAT 0620). The Harvard Semitic Museum specimen displays a long, slightly convex, top-oblique stroke. This joins the long left-to-right oblique stroke at an acute angle (partly damaged). What Hutton, Greene, and Bonesho read as an example of medial nun (line 2) seems to me a bet (see above). Monumental or cursive medial nun, in fact, never shows a head like the one visible in this case.

Samek. The only extant example, in line 2, displays a vertical right stroke, slightly round at the bottom, where it joins a long horizontal stroke. The top part consists of a two-humped stroke, the leftmost part slightly pointed. This cursive shape differs from monumental-style specimens, marked by a top convex stroke and a short rightto-left oblique tick on the left end of the stroke (e.g., PAT 0470, tomb foundation text [79 C.E.]). There are numerous other cursive examples (e.g., PAT 0792, epitaph on a funerary relief) also in vertical lines.

Tsade. In line 1, tsade looks like an uppercase N: the right stroke slightly convex, an oblique middle stroke, and a left vertical stroke with a short foot at the bottom. As in monumental-style examples, this letter closely resembles khet. Unlike in this inscription, there are examples of oblique middle-stroke tsades alongside khet with a horizontal middle bar in the same text (e.g., PAT 0968, on a funerary relief, in vertical lines, and other

${ }^{28}$ In my opinion, differences in stance are also a consequence of the fact that the inscription was carved vertically. 
examples). In cursive script, it is also very similar to the zigzag tav. As noted above, however, our inscription has not preserved this last letter.

Resh. The two specimens differ in their stance. The first (in the personal name hyrn) has a slightly convex shape, while the second one $(b r)$, an oblique stroke. No clear diacritics can be detected on the damaged surface, marked by a crack running across the head of the second specimen, chisel marks, and other small, rounded breaks.

The three Palmyrene reliefs in the collection of the Harvard Semitic Museum are not, strictly speaking, a small corpus-that is, inscriptions of related dead, possibly from the same tomb. As noted above, nothing is known about their precise findspot. Furthermore, their genealogies do not allow us to connect them and suggest they originated from the same tomb. They are, like many other Palmyrene artifacts whose provenance is not recorded, examples of funerary reliefs and epitaphs. A closer look at the inscriptions shows that the writersthe same artist who sculpted the reliefs or another craftsman?-followed conventional formulations ("name + patronym + Alas!" in the first and last case; and "statue of + name + patronym + Alas!" in the second) and variant layouts (horizontal lines to the right, in Malës relief; vertical lines to the left, in Hayran's; horizontal lines to the left, in 'Amatallat's). Not surprisingly, the script reflects three different handwritings and scripts as well as various skill levels.
The three inscriptions do not present a date formula. The inscription of Hayran, which bears distinctive cursive elements, is carved on the most recent artifact, a bust that is stylistically dated toward the end of the 2nd and the beginning of the 3 rd centuries C.E. An overview of extant examples shows that there are frequent cases of mixed monumental and cursive shapes in the same inscription, and that cursive script on stone is attested across the Palmyrene corpus alongside monumental script, and it is not used in given periods only.

\section{Conclusion}

The addition of the three Harvard Semitic Museum Palmyrene funerary reliefs provides new material for the study of Palmyrene portraiture and epigraphy. Despite the fact that they were traded in the late 19th century and reached the United States shortly thereafter, the reliefs and their inscriptions remained virtually unknown and were not included in historical editions of Palmyrene texts, such as the Corpus Inscriptionum Semiticarum. Due relevance has been given here to an in-depth analysis of the history of their acquisition, conducted on documents and correspondence from the Harvard Semitic Museum's files. Provenance and details of acquisition of archaeological artifacts have always been an issue of foremost importance, and it is particularly relevant nowadays.

\section{Acknowledgments}

Hutton, Greene, and Bonesho gratefully acknowledge research support generously granted by several agencies. The Office of the Vice Chancellor for Research and Graduate Education of the University of Wisconsin-Madison supported Greene and Bonesho's travel to photograph the inscriptions and the purchase of some photographic equipment. A grant from the Middle Eastern Studies Program at the University of Wisconsin-Madison was used to purchase additional photographic equipment, and funding from the University of Wisconsin's Mosse-Weinstein Center for Jewish Studies and the West Semitic Research Project supported photographic training. Hutton's travel to Cambridge to inspect the inscriptions was supported by the Harvard Semitic Philology Workshop, and his research was supported by a Vilas Research Fellowship, administered by the University of Wisconsin-Madison's Office of the Vice Chancellor for Research and Graduate Education. We would also like to express our appreciation to Joseph Greene, deputy director and curator of the Harvard Semitic Museum, Adam J. Aja, assistant curator of collections of the
Harvard Semitic Museum, and Martha Richardson, collections manager and registrar for the Collection of Historical Scientific Instruments, Harvard University, for their help in organizing the photographic session and providing additional information concerning the acquisition of the objects on which the inscriptions occur. We also owe a debt of gratitude to Brian and Lisa Greene (Sudbury, MA) and Cynthia Matthews (Cambridge, MA), who generously provided housing for the research team and, in the case of the latter, provided assistance with the photography.

Cussini would like to thank The Johns Hopkins University for the postdoctoral grants that allowed travels to the Harvard Semitic Museum and other U.S. museums. She is grateful to J. A. Armstrong, then assistant curator of collections, Harvard Semitic Museum, who kindly showed her the information regarding acquisition of the reliefs and the letters discussed in this article. As always, she fondly remembers Del Hillers, and wishes to dedicate her discussion of the Harvard Semitic Museum's Palmyrene reliefs to his memory. 


\section{References}

Aggoula, B.

1991 Inventaire des inscriptions hatréennes. Bibliothèque archéologique et historique 139. Paris: Geuthner.

Albertson, F. C.

2012 Two Unpublished Palmyrene Funerary Reliefs in North American Museums. Syria 89: 151-62.

As'ad, K. al-; Gawlikowski, M.; and Yon, J.-B.

2012 Aramaic Inscriptions in the Palmyra Museum: New Acquisitions. Syria 89: 163-84.

Cantineau, J.

1936a Grammaire du palmyrénien épigraphique. Publication de l'Institut d'Études Orientales de la Faculté des Lettres d'Alger 4. Cairo: Institut Français d'Archéologie Orientale.

1936b Inventaire des inscriptions de Palmyre, Fasc. 8: Le dépot des antiquités. Publications du Musée National Syrien de Damas 1 (8). Beirut: Imprimerie Catholique.

Colledge, M. A. R.

1976 The Art of Palmyra. Studies in Ancient Art and Archaeology. London: Thames \& Hudson.

Cussini, E.

In press Palmyrene Cursive and Everyday Writing at Palmyra. In Life in Palmyra, Life for Palmyra: Studies in Memory of Khaled al Asa'ad (1934-2015); Proceedings of the Conference Held in Warsaw, 21-22 April 2016, ed. M. Gawlikowski, D. Wielgosz-Rondolino, and M. Żuchowska. Warsaw: Institute of Archaeology, University of Warsaw.

Dentzer-Feydy, J., and Teixidor, J.

1993 Les antiquités de Palmyre au Musée du Louvre. Paris: Réunion des Musées Nationaux.

Drijvers, H. J. W., and Healey, J. F.

1999 The Old Syriac Inscriptions of Edessa and Osrhoene: Texts, Translations and Commentary. Handbook of Oriental Studies 1, The Near Middle East 42. Leiden: Brill.

Greene, N. E.; Heyn, M. K.; and Hutton, J. M.

2012 A Re-Edition of PAT 738 (CIS 4379). MAARAV 19: 91-115.

Heyn, M. K.

2010 Gesture and Identity in the Funerary Art of Palmyra. American Journal of Archaeology 114: 631-61.

Hutton, J. M., and Klein, K. M.

2018 Two Palmyrene Funerary Stelae in the Collection of the American Academy in Rome. Journal of Northwest Semitic Languages 44 (1): 29-40.

Hutton, J. M.; Kumon, H.; McLaughlin, M.; and Atwood, P. L. Forth- Two Palmyrene Funerary Busts in the Collection of coming the Nelson-Atkins Museum of Art, Kansas City, Mo. Ingholt, $\mathrm{H}$.

1928 Studier over Palmyrensk Skulptur. Copenhagen: Reitzel.
Kleiner, D. E. E.

1977 Roman Group Portraiture: The Funerary Reliefs of the Late Republic and Early Empire. Outstanding Dissertations in the Fine Arts. New York: Garland.

Klugkist, A. C.

1983 The Importance of the Palmyrene Script for Our Knowledge of the Development of the Late Aramaic Scripts. Pp. 57-74 in Arameans, Aramaic, and the Aramaic Literary Tradition, ed. M. Sokoloff. Bar-Ilan Studies in Near Eastern Languages and Culture. Ramat-Gan: Bar-Ilan University Press.

Mackay, D.

1949 The Jewellery of Palmyra and Its Significance. Iraq 11: $160-87$.

Meischner, J., and Cussini, E.

2004 Vier Palmyrenische Grabreliefs im Museum von Antakya. Archäologischer Anzeiger 2003 (2): 97-105.

Naveh, J.

1975 An Aramaic Inscription from El-Mal-A Survival of "Seleucid Aramaic" Script. Israel Exploration Journal 25: 117-23.

1976 Syriac Miscellanea. 'Atiqot 11: 102-4.

2009 Studies in West Semitic Epigraphy: Selected Papers. Jerusalem: Magnes.

$P A T=$ Hillers, D. R., and Cussini, E.

1996 Palmyrene Aramaic Texts. The Comprehensive Aramaic Lexicon Project. Baltimore: Johns Hopkins University Press.

Pirenne, J.

1963 Aux origines de la graphie syriaque. Syria 40: 101-37.

Ploug, G.

1995 Catalogue of the Palmyrene Sculptures, Ny Carlsberg Glyptotek. Copenhagen: Ny Carlsberg Glyptotek.

Sadurska, A., and Bounni, A., with the collaboration of K. alAss' ${ }^{\mathrm{C}}$ d and K. Makowski

1994 Les sculptures funéraires de Palmyre. Supplementi alla Rivista di Archeologia 13. Rome: Bretschneider.

Sokołowski, Ł.

2014 Portraying the Literacy of Palmyra: The Evidence of Funerary Sculpture and Its Interpretation. Études et travaux 27: 376-403.

Stark, J. K.

1971 Personal Names in Palmyrene Inscriptions. Oxford: Clarendon.

Zanker, $\mathrm{P}$.

1993 The Hellenistic Grave Stelai from Smyrna: Identity and Self-Image in the Polis. Pp. 212-30 in Images and Ideologies: Self-Definition in the Hellenistic World, ed. A. W. Bulloch, E. S. Gruen, A. A. Long, and A. Stewart. Hellenistic Culture and Society 12. Berkeley: University of California Press. 